\title{
Signos de los tiempos y metáfora Una estética de los signos de los tiempos
}

\author{
CÉSAR CARBULLANCA NúÑEZ \\ Universidad Católica del Maule (Chile) \\ ccarbullanca@ucm.cl
}

\begin{abstract}
Resumen
El artículo es un esbozo de una estética de los signos de los tiempos, el cual propone en base a la categoría nietzscheana de metáfora, una heurística de los signos de los tiempos en la historia latinoamericana. Este esbozo pretende una lectura de Latinoamérica desde una nueva base epistemológica 'dejando sin habla' los supuestos metafísicos mediante una retirada a la metáfora de los signos de los tiempos en su emergencia original. Para lo cual se exponen las metáforas de la infancia como emergencia de una nueva era, entendida como inversión cósmica y epistemológica, las metáforas relativas al martirio y a la señal de Jonás, y finalmente, exponemos metáforas que relacionan revelación y signos de los tiempos, para esto estudiamos las metáforas del 'pasar a la otra orilla' y las del 'enigma' y la interrogación.
\end{abstract}

Palabras clave: signos de los tiempos, metáfora, estética, epistemología, teología bíblica.

\section{Signs of the times and metaphor Aesthetics of the signs of the time}

\begin{abstract}
The article is an outline of an aesthetic of the signs of the times, which proposes the category based on Nietaschean metaphor, a beuristic of the signs of the times in Latin American history. This sketch of an aesthetic seeks a deconstructive reading that produces a new epistemological basis 'left speechless' metaphysical assumptions by a withdrawal to the metaphor of the signs of the times in its original emergency. We describe the metaphors of childhood as emergence of a new era, and understood as cosmic investment epistemological metaphors relating to martyrdom and the sign of Jonah, and finally, we present disclosure relate metaphors and signs of the times, for which we study metaphors of 'pass to the other side' and the 'enigma' and interrogation.
\end{abstract}

Key words: signs of the times, metaphor, aesthetics, epistemology, biblical theology.

Doctor en Teología por la Universidad Pontificia de Comillas (España). Sacerdote de la diócesis de Talca. Profesor de Sagrada Escritura en la Facultad de Ciencias Religiosas y Filosóficas de la Universidad Católica del Maule. Entre sus publicaciones recientes cabe mencionar "El discípulo amado: una clave hermenéutica de la cristología joánica" (2008), "Los Cánticos del Sacrificio Sabático. Aproximaciones al estudio de la mística judía" (2009), "Orígenes de la cristología del cuarto evangelio. El problema de unidad literaria y teológica" (2010) y “¿Una teología del martirio en 1QHa y 4Q491c? Aportes para la comprensión de la cristología del Hijo del hombre joánico” (2011).

Este artículo forma parte del proyecto Fondecyt $N^{\circ} 120029$. 
El tránsito de una Iglesia de cristiandad a otra centrada en los signos de los tiempos es uno de los desafíos teológicos centrales de la época moderna. No es casual que el Concilio en la Constitución Gaudium et spes 4-5, hable abundantemente de este proceso de transformación que vive la humanidad y la Iglesia: «el género humano se encuentra en una nueva era», "podemos hablar hoy de una autentica transformación social y cultural, que influye también en la vida religiosa».

En este contexto, el Concilio Vaticano II en la constitución Gaudium et spes, 4, introducía el tema de los signos de los tiempos, apelando al «deber permanente de la Iglesia escrutar a fondo los signos de la época e interpretarlos a la luz del Evangelio, de forma que, acomodándose a cada generación, pueda la Iglesia responder a los perennes interrogantes de la humanidad sobre el sentido de la vida presente y de la vida futura y sobre la mutua relación de ambas». Se podría adelantar a modo de hipótesis una pregunta ¿no estaría el Concilio y antes de éste, el papa Juan XXIII, usando este lexema, en el horizonte de una interpretación apocalíptica de la historia de la Iglesia en la modernidad? Es posible que la mención de esta metáfora, sea algo más que una ilustración y esté entregando un horizonte de comprensión de la historia e identidad eclesial en la modernidad. Por tanto, la dialéctica 'transformación-metáfora' que establece el documento aporta una relación hermenéutica que muestra un paisaje que la teología debe transitar e investigar.

J. Noemi (2008: 85) menciona en su artículo la necesidad de superar la insuficiencia metodológica de una yuxtaposición entre el diagnóstico empírico al de una interpretación teológica del presente, llamando a esta yuxtaposición 'una insuficiencia metodológica' asumida más o menos automáticamente por los documentos magisteriales. La Constitución Gaudium et spes se vale de la expresión 'signo de los tiempos' para formular una clave teológica para interpretar la eclesialidad en el mundo presente. Pero esta expresión menta una relación metafórica entre los elementos de la oración, pues muestra algo insólito, paradójico o como diría Ricoeur, en relación a la metáfora, representa una «innovación semántica» (1984: 54). Dicha insuficiencia metodológica difícilmente se puede superar si no es enfrentando el desafío teológico, expresado por las palabras que J. Derrida dirige a los filosóficos (pero que también alcanza a teólogos): «Los metafísicos... [son] un montón de tristes poetas, despojan los colores de las antiguas fabulas y son ellos mismos sino recolectores de fabulas: productores de la mitología blanca» (1974: II). Los conceptos metafísicos, tales como historia, persona, substancia y otros con los cuales se ha alzado la filosofía de occidente son - usando la terminología nietzscheana- 'monedas gastadas' que han perdido su valor de uso (Nietzsche, 1998: 25). En este contexto H. Sander (2003: 51-61) 
sostiene el precario lugar de la dogmatica y se pregunta si 'se espera que la dogmática católica sea una monótona presentación de sí misma’. Y también G. Ruggieri en su artículo Zeichen der Zeit, habla de «das Defizit der Theologie der Zeichen der Zeit» y se pregunta «isi la deficiencia de una teología de las señales de los tiempos en la reflexión teológica de Occidente son al mismo tiempo una deficiente experiencia teológica de la Iglesia de Occidente en nuestro tiempo?» (2006: 61-70). También Noemi (1998: 29) sostiene la necesidad de volver a un mito-logos que permita pensar Latinoamérica desde la fe. H. Sander postula que en esta situación de precariedad de la teología se requiere de «Eine kreative Sprachlosigkeit macht sich auf die Suche nach einer neuen Sprache» (2003: 61) la cual comienza con la transformación del lenguaje. Nosotros queremos vincular dicha transformación postulada por Sander con la crítica nietzscheana a la razón, que sustenta la hipótesis, a saber, que mediante esta Sprachlosigkeit de la razón conlleva una retirada a la imaginación mítico-poética de los textos lo cual recupera teológicamente la alteridad, emergencia del sentido teológico y el ethos cultural que vio nacer los relatos relativos a una teología de los signos de los tiempos.

El presente artículo - que pretende ser un diálogo teológico con la teología especulativa-, es un esbozo de una estética de los signos de los tiempos, con el objeto de proponer, en base a la categoría nietzscheana de metáfora, una heurística de los signos de los tiempos en la historia latinoamericana. Este esbozo pretende una lectura de Latinoamérica desde una nueva base epistemológica 'dejando sin habla' los supuestos metafísicos mediante una retirada a la metáfora de los signos de los tiempos en su emergencia original. Desde un punto de vista metodológico, las reflexiones tiene dos premisas fundamentales: la primera la concepción nietzcheana de metáfora y segundo, el análisis de los textos fundados en la metodología de una antropología de lo imaginario por G. Durand (2004). Ambas perspectivas aportan un estudio de isotopías mítico-sicológicas que aportan: modelos, paradigmas y criterios que posibilita una operatividad teológica de la categoría 'signos de los tiempos' (Berrios, Costadoat y García, 2008: 93). Para G. Durand el análisis textual se traduce como un estudio de las 'mitemas' o metáforas, que coincide con una 'metaforología' mencionada por J. Derrida (2007: 28).

El artículo expone en la primera parte, en conformidad con esta 'kreative Sprachlosigkeit' que afirma Sander, la necesidad de un 'creativo silencio' de los supuestos metafísicos y retornar a la Sagrada Escritura como condición para una teología de los signos de los tiempos cristiana, subrayando la diferencia que media entre nuestra visión del mundo y la de aquellos; posteriormente, realiza una lectura estética de los signos de 
los tiempos, esto quiere decir, elaborar una nueva base epistemológica 'haciendo callar' los supuestos metafísicos, sosteniendo la diferente temporalidad que media entre aquel tiempo y el nuestro; a continuación proponemos pensar Latinoamérica desde las metáforas de la infancia como emergencia de una nueva era, la cual es entendida como inversión cósmica y epistemológica; posteriormente, pensar Latinoamérica desde las metáforas relativas al sufrimiento y la temporalidad, como son las metáforas relativas al martirio y a la señal de Jonás; finalmente, desde metáforas que establecen una vinculación entre revelación y signos de los tiempos. En este apartado, mencionamos dos aspectos: las metáforas del 'pasar a la otra orilla' y las que hacen relación con el 'enigma' y la interrogación.

\section{La metáfora en la Sagrada Escritura}

\subsection{Estética y retorno a la Sagrada Escritura}

Apelar a una teología de los signos de los tiempos que responda a la transformación de una época, significa discutir el papel de la metáfora y de la imaginación en el discurso filosófico y teológico. Este reajuste significa una 'Sprachlosigkeit', un hacer callar, conceptos metafísicos, como causalidad, persona, historia, mundo, etc., utilizados por la teología cristiana por siglos. No es casualidad que los grandes filósofos del siglo XIX y XX tales como F. Nietzsche, J. P. Sartre, M. Heidegger y P. Ricoeur, hayan dedicado sendas reflexiones al papel del lenguaje poético y de la imaginación y su relación con la configuración de la temporalidad (Sartre, 1973; Lapoujade, 1988: 23-101; Heidegger, 1954). La teología especulativa, dichas incursiones de la literatura o poética, las ha clasificado con el membrete - peyorativo- de 'teo-poiética', y ha reducido la estética a un tema periférico que poco y nada aporta a la discusión de una teología de la historia, pero ésto se vuelve hoy imposible, pues se trata de un hecho epistemológico de innegable envergadura. No tiene que ver con un nuevo apartado de la teología, ni un nuevo tipo de teología, sino de un derrumbe epistemológico que ha ocurrido y que afecta al quehacer teológico. Louis Marie Chauvet, ha sostenido una superación de la metafísica como condición de una la teología sacramental (1991: 54-90); así también, nos parece, una teología de los signos de los tiempos debe asumir, si se pretende erigir en un discurso sobre Dios relevante y con sentido, una cesura/ruptura epocal con el paradigma lógico-especulativo de una teología cimentada en la metafísica y que ha mediado durante siglos. Una vuelta a la estética 
pretende una 'retirada', un recurso, a la metáfora y al mito' en tanto esto es una recuperación del mito-logos, del sentido primitivo y heurístico de los textos bíblicos. Entonces esto, no debiera entenderse como un escarceo en terrenos considerados ajenos y propios del frio razonamiento teológico, más bien la propuesta de J. Derrida que se constituye en un programa que deconstruye el lenguaje metafísico postula que este acercamiento desde la estética, es lo propiamente filosófico y teológico que requiere 'retirarse a su ser más íntimo' (Derrida, 1978; Agis, 1991: 301-316). Una teología de los signos de los tiempos, según esto, debe pues volverse al suelo originario de los textos bíblicos que hablan de la experiencia primera de la metáfora más atrás del levantamiento y del uso de la metafísica que hará la teología. En el área de los estudios bíblicos $\mathrm{K}$. Berger sostiene una posición similar: «para muchos ámbitos de la existencia, el modo estético (metafórico) de hablar es el único adecuado» (Berger, 2011: 96). En su estudio Berger, sostiene la necesidad de estudiar 'el lugar sociosicológico de la metáfora', por ejemplo en relación al los textos que habla del 'vestido' (por ejemplo, Jn 21,7; Ef 4,24) menciona: 'el lugar sociosicológico del vestido'... pues 'el valor social de una persona depende en alta medida de aquello que se usa como un vestido'... las vestiduras indican 'una posición jerárquica social de las respectivas personas' (Berger, 2011: 73).

\subsection{Las metáforas del tiempo bíblico}

Un aspecto paradojal de la discusión sobre una teología de los signos de los tiempos es la ausencia de estudios bíblicos (Hünermann, 2006), reduciendo la discusión al texto de Mt 16,1-3; lo cual conlleva la casi completa falta de la reflexión teológica en relación con esta teología bíblica de los signos. En relación al primer aspecto, Luis Carvajal se queja por la falta de estudios bíblicos dedicados al tema: «[...] un concepto que casi nadie se ha molestado en estudiar tenia necesariamente que caracterizarse por la imprecisión» (Carvajal, 1987: 2223). Esta queja no deja de tener razón. El libro de A. González y un escrito por el autor, además de otros significativos aportes ayudan a llenar este vacío (González, 2003: 306-366; Carbullanca, 2008: 649-672). Pero a esta falta de estudios bíblicos, se añade, la ignorancia de la teología especulativa acerca de esta categoría bíblica como si no existiese detrás del texto de Mt 16,1-3 una concepción de la historia y de los signos que presagian el final de los tiempos. Más bien ocurre que el texto de Mt 16,1-3 sirve de excusa para realizar las más variadas disquisiciones sobre el tema. 
Desde los estudios de F. Nietzsche en el siglo XIX, hasta los de G. Lakoff y M. Johnson, sabemos que la metáfora no se reduce al campo de la retórica sino que es «un aspecto permanente en la vida cotidiana, no sólo en el lenguaje sino en el pensamiento y la acción» (Lakoff y Johnson, 2003: 4). En todos estos estudios se subraya, por un lado, que el lugar de la metáfora se extiende más allá de los relatos poéticos o filosóficos, ella está omnipresente en los más diversos géneros literarios; y por otro, y más importante, estos escritos subrayan al suelo prelingüístico de la metáfora. En esta misma perspectiva, nuestro estudio acerca de los signos de los tiempos requiere averiguar 'el lugar sociosicológico' de la metáforas relativas a las señales del eschaton. Es este contexto originario el que ayuda a recuperar la alteridad del texto y la pragmática a la que responde la expresión en textos neotestamentarios. La emergencia de esta metáfora debe atender a que el referente esencial que subraya el lenguaje profético y netotestamentarios hace relación con la historia humana y más en particular se refiere a la utopía del eschaton. Este periodo de la historia se encuentra en el límite y sólo es posible acceder a él a través de imágenes utópicas que evocan este tiempo de manera metafórica con diversos fenómenos cósmicos, como personajes o hechos temporales que posee una significación en función de identificar, exhortar o legitimar la misión divina del enviado como a su vez muestran ostensiblemente el arribo del eschaton.

\subsection{Mito-logos y metáfora}

J. Noemi al constatar el patente esquematismo de la teología latinoamericana señala que si bien el marco teórico del análisis sociológico puede ser útil, no logra hacerse cargo complexivamente de la riqueza que encuentra la realidad latinoamericana y condiciona un estrechamiento epistemológico de 'la teología resultante'. Noemi constata un 'logos riquísimo' en la poética y novelística de un Neruda, García Márquez, que perdura como un 'mito-logos' y sostiene la necesidad de un «tránsito del mito-logos a un logos filosófico esta apenas en sus inicios. La teología se resiente de esta situación. El teólogo le echa en menos al filósofo que le desentrañe y articule el mito-logos del poeta» (Noemi, 1998: 29). Este tránsito de un mito-logos a otro filosófico es la tarea de desentrañar la metáfora y 'pensar Latinoamérica desde su fe'.

Esta crítica resulta contrastante si la confrontamos con la reflexión filosófica y sicológica del siglo pasado que ha sido fecundada precisamente por este recurso al mito y la metáfora - pensemos en los aportes en el área de la sicología profunda de Freud, Jung y en la filosofía de Nietzsche y Marcuse-. Hay que decir además, que una cuestión no 
suficientemente valorada desde la teología, es el recurso al mito que ha introducido tanto la Teología de la Esperanza y la Teología de la liberación, al rescatar el paradigma bíblico de la promesa, el mito del éxodo y la categoría de liberación. La articulación de la triada: mitomediación-praxis que desarrollan estas teologías representan un modelo similar al que otros intentos teóricos -sicológicos y filosóficos-, del siglo XX han desarrollado en diferentes áreas del pensamiento para desentrañar el mito-logos en términos actuales. A juzgar por esto, quizás no es objetiva la opinión de Noemi (2008: 85) al señalar que dicha articulación pareciera ser una «aporía insuperable». J. Moltmann en su Teología de la Esperanza establece la triada: paradigma de 'la promesa'filosofía de la esperanza de E. Bloch-praxis política. Algo similar encontramos en el esquema seguido por la Teología de la Liberación. Es indudable la emergencia de la metáfora, tanto en el ámbito del inconsciente personal y colectivo así como en el político-utópico durante el siglo pasado. El siglo XX se ha caracterizado por el esfuerzo teórico por desentrañar el logos metafórico inconsciente o utópico mediante una hermenéutica de la sospecha que haga operativa una terapéutica social o personal, pero a la verdad, la teología especulativa mira dichos intentos sin hacerse cargo de la crítica de Sander 'una monótona presentación de lo mismo', habla de Heidegger sin asumir a Heidegger, habla de Zubiri sin asumir a Zubiri, discute de modernidad y post-modernidad sin asumir los correspondientes desafíos que todo esto implica para el pensar teológico. Con todo, pareciera, que en general una teología de los signos de los tiempos, tendría que asumir el dialogo con una teología bíblica, poniéndose al día en esta tarea del recurso a su propio mito-logos de los relatos neotestamentarios, que emerge habitualmente en relación a la utopía, desarrollada por grupos judíos y cristianos marginales. Ciertamente, no podría ser de otro modo, el recurso a la metáfora tanto filosófica como bíblica es para la fe cristiana un referente ineludible que nos entrega claves hermenéuticas para realizar este transito propio que vuelva operativo el discurso teológico.

\section{Una lectura estética de los signos de los tiempos}

Una estética de los signos de los tiempos debe establecer un análisis contextual de los mitemas o metáforas presentes en la cultura que los vio nacer, este análisis es semejante al realizado por Levi-Strauss (1964) relativo al análisis estructural del mito; a este carácter correlativo de la análisis metafórico se debe que frecuentemente en nuestra exposición nos refiramos a los conceptos de isotopías y de paradigmas míticos. 
Dicho esto, en los siguientes apartados, pretendemos, pensar Latinoamérica desde las metáforas; primero, de manera negativa, sentar las diferentes percepciones sobre la temporalidad e historia que existe en la Sagrada Escritura y en nuestro propio tiempo; segundo, estudiaremos la metáfora del niño y su relación con el carácter revolucionario de las señales de los tiempos; tercero, estudiaremos, el carácter emocional y experiencia de la temporalidad semita y finalmente estudiaremos, la relación entre revelación entendida como pregunta y su relación con los lugares donde el Dios cristiano se muestra.

\subsection{Pensar una diferente temporalidad}

Es importante comenzar negando el lugar común que sostiene la idea que en los textos de la Sagrada Escritura existe solamente una concepción lineal de la historia. Es posible mostrar que durante el periodo bíblico existieron no sólo una sino varias comprensiones de la temporalidad y la historia. Ciertamente existe la perspectiva afirmada durante el siglo pasado por R. Bultmann, O. Cullmann, Ch. Dodd, pero a la vez, hay que afirmar que es muy diferente al concepto de historia inmanente y lineal al que nosotros estamos acostumbrados. La exegesis del siglo pasado, con su concepto positivista de la historia pretende afirmar la historicidad de los hechos desmitologizando la imaginería neotestamentaria. Nosotros pretendemos mostrar que precisamente se conserva la historicidad de los hechos no a costa de su estructura mítica sino explicitando su propia emergencia histórica.

En la expresión usada relativa a una teología de los signos de los tiempos entendida como una teología de la historia hay que preguntarse en cada autor ¿qué concepto de historia se está utilizando? ¿Qué uso, a qué tipo de pragmática historia responde la expresión estudiada?

Para el hombre moderno, la historia es una categoría inherente al ser humano y por tanto el sujeto propio de ésta es el hombre, y por consiguiente para desmitologizar el mensaje bíblico, se requiere traducir a categorías modernas todo lo que se relacione al mito. Al contrario, en una lectura estética se requiere aceptar una lógica diferente, aceptar que en la Escritura la historia es guiada por la palabra de Dios, las causas que mueven la historia, no son de orden metafísico ni inmanente, sino que ocurren en los cielos, de acuerdo a los decretos divinos. Dios conduce la historia de acuerdo a un plan pre-establecido y de acuerdo a épocas o periodos. Es importante entender que si bien la convicción en el señorío de Yahvéh sobre la historia fue un lugar común, el desarrollo de dicho plan fue comprendido de diverso modo por los distintos grupos que conformaron el judaísmo tardío. Cada libro y cada grupo tuvieron su 
particular manera de comprender la historia y el eschaton e incluso dentro de un mismo escrito se puede comprobar evoluciones del concepto de temporalidad.

El nacimiento de la reflexión historiográfica tanto en el mundo semita como helenista está en relación al mito (Heródoto, 1990,28.75). La historia es producto de las fuerzas divinas que actúan en el devenir humano y que la mayor de las veces explica las causas de este. El periodo bíblico en que nace formalmente la preocupación por el sentido de la historia coincide con el nacimiento de las corrientes apocalípticas judías que utilizan diversas expresiones para describir el devenir, por ejemplo, 'exegesis', 'diegesis', 'midrash' (ver Gn 37,2; Jc 7,15; 2Cro 13,22; 2Cro 24, 27) que quiere denotar la historia narrada'; otras semejantes como las

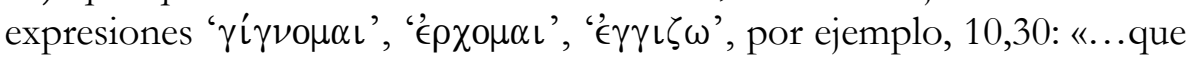

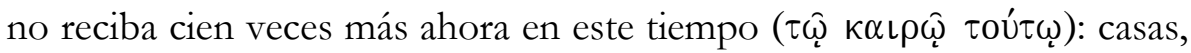
hermanos, hermanas, madres, hijos y campos, con persecuciones; y en la

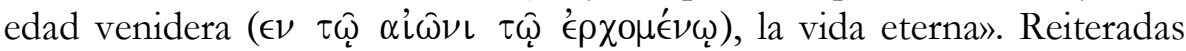
veces el advenimiento del eschaton se expresa mediante los verbos

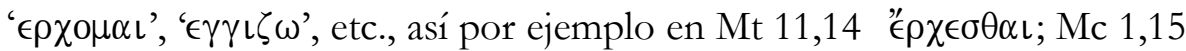

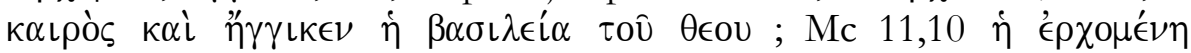

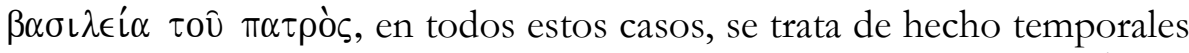
vinculados a personas o eventos sociales. La expresión ó $\alpha i \grave{\omega} \nu$ ó

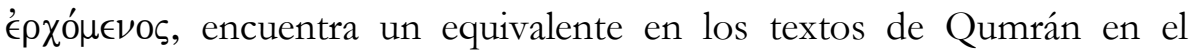
verbo ' $\tau \cup \chi$ ' (cf. CD-A col. VII, 10; CD-B col. XIX, 7-10; 1Q22 col I., 8) que expresan el carácter de evento, acontecimiento histórico. Esta terminología apunta, a que la temporalidad es vivida como producto de una voluntad personal divina y no es entendida en término impersonales, mecánicos o causales como es en nuestro medio, por eso se piensa que 'el futuro viene' porque depende de la voluntad personal de Dios. Los procesos históricos son causados por alguna palabra decretada en los cielos. Dios y su palabra vienen desde el futuro el hombre está detenido; nuestra cultura cree al contrario, que el hombre avanzar hacia el futuro a partir de las causas sedimentadas en nuestro pasado. Para el mundo semita, la diferencia entre temporalidad y mundanidad es difusa y más bien pareciera que mundo y temporalidad son magnitudes que se superponen de manera que cuando se dice que 'el futuro viene a nuestro encuentro' implica decir el 'mundo futuro' o 'la condenación'.

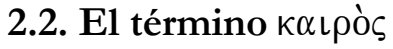

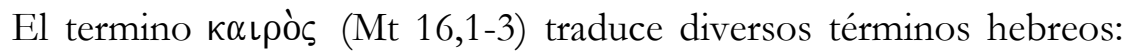
' $\sigma \gamma \nu$ ', ' $\gamma$ ', el cual tiene en la apocalíptica judía una connotación 
'experiencial-sicológica', 'emotiva', se trata del tiempo o periodo de ceguera, de la ira, de prueba o de persecución, así, por ejemplo encontramos en textos de Qumrán, una serie de textos que mencionan el martirio como experiencia del tiempo CD VII, 10-21; «tiempo de la impiedad» $\rceil \gamma \alpha \rho \varpi . \varepsilon \chi$, «tiempo de la aflicción», $\nu \beta \gamma, \gamma$ periodo de la ira

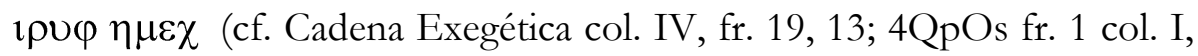
12). En todos ellos se refiere no ha una medida de tiempo neutral sino a una apreciación subjetiva de la temporalidad. Pareciera ser que el termino $i v \zeta$ traducida por 'hora', 'momento específico' en Ecl 3,1; Dn 2,16 posee una connotación más objetiva. En Eccl 3,1 «Todo tiene su hora ( $1 v \zeta)$, y todo lo que se quiere debajo del cielo tiene su tiempo $(, \gamma) »$

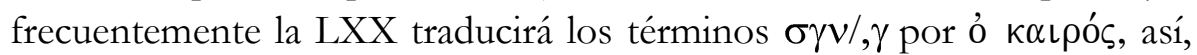

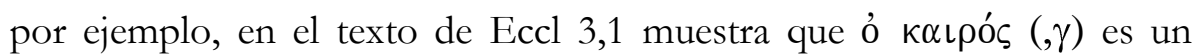
tiempo 'experiencial' y por consiguiente 'fragmentario' así, como un tiempo del reír, llorar, nacer o morir, etc. No se trata de una medida objetiva de tiempos - aunque se conozca la medida del mes, la semana y el día-, sino por un tiempo cualificado de acuerdo a la experiencia ya sea de sufrimiento como de alegría. El acento está puesto en que es una experiencia de la temporalidad 'fragmentada y porosa', en el sentido que el fluir de los acontecimientos no está regida por el principio metafísico de una causalidad natural sino por la libertad divina y por consiguiente puede ser 'intervenida' sin aviso, por eventos o personajes del pasado o que viven sencillamente en otra esfera de la realidad Los textos neotestamentarios se hacen eco de estas diversas comprensiones de la temporalidad judía (Volz, 1903: 181), así por ejemplo, añadiendo a lo ya dicho sobre el término ó kaıpós utilizado en los textos de Mc 1,14 y Mt 16,1 es traducida como 'tiempo propicio' mostrando una comprensión pesimista la historia dominada por el mal, dividida en periodos y que llegan a su punto máximo con el eschaton; por otra parte, el término de ó

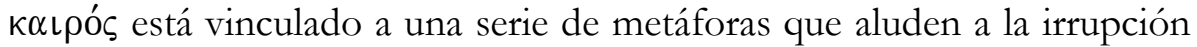
del tiempo del eschaton comprendido de diferente manera como lo muestra el relato de Mc 9, 1-10.13-15. La vuelta de Elías, aparece como una señal de los tiempos según el texto de Mal 3,23; para la comunidad marcana el lexema 'señal de los cielos' se cumple en Juan el Bautista $(9,13)$; pero esto refleja una visión de la historia muy distinta a la nuestra, en donde Dios rompe las leyes del devenir, enviando una 'persona' del pasado como señal que ha llegado el final de los tiempos. Ciertamente, la emergencia del lexema representa una característica lingüística que responde a una necesidad pragmática como son el triunfo de la justicia o la legitimación político-religiosas en el marco de la sociedad del siglo I. Para éstos grupos, el lexema 'signos de los tiempos', o 'señal del cielo' 
responden a un discurso críptico, secreto, que refleja una autocomprensión de la comunidad de los últimos tiempos. Sólo ellos reconocen en los signos la llegada del eschaton. Por tanto, se trata de un imaginario identitario, compartido y reconocido entre grupos marginales, apocalípticos y cristianos, que creyeron en el advenimiento del mundo nuevo. El relato de Mc 9, 4 resulta aleccionador. En él se aparecen las figuras de Elías y Moisés, y no es raro que se entienda este relato, en el marco de una compresión científica del mundo, en términos 'metafóricos' y no reales. Para el mundo semita, la presencia de Elías y Moisés en el Tabor, al contrario, constituyen la realidad más real. En cambio nosotros tendemos a considerar dichas imágenes como 'expresiones metafóricas' que se requiere desmitologizar. Para la temporalidad bíblica personajes del pasado irrumpen en el presente porque ellos habitan en la presencia de Dios. Y esto es narrado de acuerdo con un esquema de dos planos de la realidad en donde conecta al discípulo con el Tiempo sagrado. Las apariciones de Elías y Moisés como héroes del tiempo escatológico representan señales del tiempo final y forman una gramática que conecta cada signo con un todo que ayuda al discípulo a reconocer el tiempo verdadero y configurar su vida de acuerdo a la voluntad divina. Este dato lingüístico es importante pues coloca en directo el tema de los 'signos de los tiempos' con el 'lugar sociológico' desde el cual se utiliza. En efecto, el uso de determinados sociolectos, sirve tanto como de legitimación ideológica como criterio hermenéutico para identificar a los miembros de un grupo determinado. Entonces, una de las características de la expresión estudiada, es que se comprende en relación a un todo más global, en otras palabras, se trata de una gramática de la historia del eschaton, integrada por una serie de metáforas e imaginarios del eschaton que apuntan a una lectura de la realidad desde la escatología.

\subsection{Metáforas y contra-proyecto cultural}

En su artículo Desafíos del tiempo, memoria y esperanza, F. Parra menciona un texto de Zubiri que impresiona: «es pura y simplemente transcurso. Es un transcurso en el transcurre precisamente las posibilidades, unas ampliadas, otras reducidas; unas anuladas, otras cambiadas» (Parra, 2008: 67) En el mundo semita, habría que decir que la historia es entendida como una 'metaforización', un llevar la realidad de un punto a otro, un transcurso, Pero esto se expresa no con conceptos metafísicos, ni en términos de un paradigma científico, sino con imágenes metafóricas que remiten al paso y a la transformación de este mundo en otro completamente distinto. Una de estas imágenes del 
transcurso es la metáfora del niño que guarda relación con el de la señal de los tiempos y aparece explícito en múltiples pasajes así como Is 7, 14 «...el Señor mismo os dará señal ( $\sigma \eta \mu \in \hat{\imath} 0 \nu)$ : La virgen concebirá y dará a luz un hijo, y le pondrá por nombre Emanuel» (Mt 1, 23). Se trata de una expresión utópica ligada a corrientes profético-escatológica y se desarrolla, de manera particular, a través de variadas imágenes, y durante el periodo del judaísmo tardío en grupos apocalípticos, así por ejemplo, las figuras de Isaac, de Moisés salvado de las aguas, de la elección de David, y del futuro mesías, están apuntando a un nuevo proyecto histórico de liberación que comienza con la señal del nacimiento de un niño (ver Gn 21,3; Ex 2,2; Jc 13,7.24; 1Sa 1,24; 1Sa 17, 28). En términos generales se trata de una contra-propuesta solidaria a un modelo societario opresor En estos relatos como se puede comprobar está en directa relación con la futura y a veces inminente liberación política y económica del pueblo. En ámbitos apocalípticos, la liberación está vinculado a la metáfora de la mujer dando a luz un niño (ver Jn 16,21; Rm 8,21-22; Mt 2,11) que sugiere ya no tan sólo una liberación política nacional sino que ésta alcanza dimensiones cósmicas, a través de la antinomia viejo-niño referido a épocas o eras de la historia de la humanidad; y a la del asesinato del niño sucesor del reino (ver Ex 2,10; Gn 22,11; 1Sa 20,23; Mt 1,23; Ap 12,4). En la cultura helenista la metáfora es conocida por Heródoto en Historias (1990) y el fragmento 52 de Heráclito: 'El tiempo es un niño jugando, jugando a los dados'. El filósofo del cambio perpetuo este pensando en esta imagen para expresar la temporalidad que se recrea en base al olvido. Así también en Heródoto, se trata de una profecía del cambio de un reino a manos de niño. Entonces, pareciera que estamos ante una metáfora del cambio temporal.

Este paradigma mítico es apropiado en la praxis de Jesús en diferentes contextos, aplicado no a sí mismo como se podría esperar sino a personajes insignificantes o marginados: a veces aplicado a niños $(\mathrm{Mt}$ 19,13; Mc 10,13), en otras aplicadas a los discípulos (ver Mt 11,25; 18,3). El niño constituye el paradigma de un proyecto societario solidario y ecológico que emerge bajo la imagen del juego y la gratificación que se contrapone a un proyecto militar o faraónico (ver Ex 2, 1; Is 9,11; Mt 1, 23). Este aspecto refleja una subordinación del poder político y militar a otro principio de liberación más bien estética en el cual, la nueva era no es mediada ni viene a consecuencia del arribo al poder político del mesías, sino de la propia praxis del liberador. El sentido tautológico que presenta la praxis estética de Jesús es manifiesto, y refleja el carácter antimesiánico de la praxis de Jesús que explica en definitiva la epistemología 
de la cruz propuesta por el relato marcano de la pasión. El arribo del

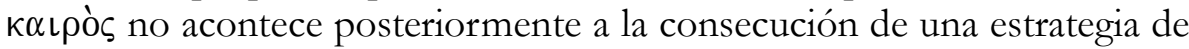
alianza con el poder político, sino en su propia praxis anti-mesiánica, de comer y solidarizar con pecadores, sanar enfermos, acoger a excluidos,

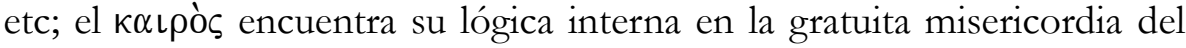
Padre.

Pero además, la metáfora de la infancia, representa una tradición que sostiene una ruptura epistemológica con el antiguo orden. En este sentido, la imagen del niño muestra una vinculación con la tradición profética en cuanto es el profeta el que discierne y reconoce los signos salvificos en la historia. Esta tradición, que atraviesa tanto al judaísmo como al cristianismo, se aprecia en el uso reiterado de Is 6,9 , que remite al principio epistemológico apocalíptico que hemos llamado 'principio de ignorancia' y que emerge en diversos relatos como Mc 4,11-12; 13, 32 (ver Jub 1,13) y en la fuente de los dichos ( Lc 10,21) «...Yo te alabo, Padre, Señor del cielo y de la tierra, porque escondiste estas cosas de los

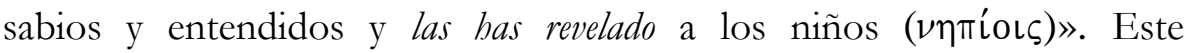
principio de - esconder a unos y revelar a otros-, es asumido por los relatos neotestamentarios, según el cual el reconocimiento de los signos de la presencia del reino es una revelación gratuita y selectiva del Padre a los elegidos (niños) y que ha sido ocultado a los sabios y poderosos. Esta intencionalidad divina de 'ocultar' la revelación a los sabios y poderosos es notable, pues muestra que la revelación del Dios del reino es una revelación 'selectiva', que constituye en profetas y sujetos del eschaton a determinados personajes excluidos de la historia. Con esto, queremos hacer notar, la importancia del estudio de las metáforas de la infancia en relación al concepto de revelación, pues estas muestran que la revelación es reconocida por los que son 'como niños' y por tanto que están contrapuestos a los 'sabios y poderosos' de este mundo. Con esto, estamos señalando que esta metáfora introduce no sólo el tema del cambio de época sino que además introduce la necesidad de un cambio epistemológico, a saber, determinados sujetos, que se les otorga en su calidad de niños la revelación profética del reconocimiento de las acciones divinas.

Este protagonismo de los niños a partir del reconocimiento de los signos de los tiempos, nos recuerda aquel de las bienaventuranzas referida a los mártires y pobres: ellos son sujetos escatológicos. Costadoat al postular que el lugar hermenéutico de interpretación eclesial sea el del mundo de los pobres advierte que significa un «principio de una revolución de enorme magnitud» (Costadoat, 2008: 144). Y en palabras de G. Durand (2004: 402), se trata de la revolución microcósmica donde lo 
pequeño se vuelve grande, lo último, primero. El reinado de Dios se anuncia de acuerdo al texto de Is 61,1, que habla de los signos del profeta ungido por el Espíritu, convirtiéndolos en sujetos sociales en un contexto en que se esperaba que los protagonistas fuesen otros sectores de la sociedad judía. En este sentido es fundamental hacer notar que se comete un error teológico al hablar de los pobres como destinatarios de la Buena Nueva, cuando en realidad los textos hablan más bien que éstos son los protagonistas del reino. De acuerdo a los hallazgos realizados en Qumrán, hay testimonios (ver 11QMelq; 4Q521) de que el texto de Is 61, 1-2 se comenzó a utilizar a mediados del siglo II a.C., para identificar tanto al profeta escatológico como a los elegidos para participar del gobierno de Dios, esto es, con los pobres, oprimidos, cautivos, ciegos, cojos. A esto se debe que en el NT se mencionan listas de sujetos escatológicos' (ver Lc 7, 21s). El mensaje de las bienaventuranzas se hace eco de esta forma literaria, proclamando una lista de sujetos escatológicos, así lo atestigua Lc 6, 20. La praxis liberadora de Jesús se apropia de esta profecía vinculándolos a diversos sujetos marginados: niños, pobres, leprosos, paganos, etc. Los movimientos marginales del judaísmo creyeron ver de acuerdo a la expectativa formulada en el texto de Is 61,1-2, la irrupción del eschaton, el fin de una sociedad excluyente. Es notable como Jesús se apropia de esta esperanza profética al señalar que el gobierno de Dios les pertenece a los excluidos ${ }^{1}$.

Sumario. Las metáforas ligadas a los signos de los tiempos son las metáforas de la infancia que guardan relación con el comienzo la irrupción de una nueva era mundial. Esta nueva era, contiene caracteres políticos e históricos, de manera particular establece que a esta nueva época le acompaña una ruptura epistemológica según lo cual, los signos de los tiempos se les revelan a los niños y se les ocultan a los impíos. Se trata de una inversión epistemológica en donde la acción política está comprendida a partir de la gratuidad estética de la praxis del Reino. En este sentido, una criteriología de los signos de los tiempos, postulada por Markus Vogt (2006: 123-124) debe integrar la 'parcialidad' y el carácter conflictivo que es inherente a la categoría de los signos. Son determinados sujetos los que reconocen los signos de la presencia del eschaton. Pero además expresa que esta revelación de los signos de la presencia del eschaton, legitima y constituye en profetas y sujetos del

\footnotetext{
1 Es posible que alguien se sorprenda de esta lectura pero remito a otros textos en donde se promete a los seguidores de Jesús juzgar a las doce tribus, de manera similar a lo que se esperaba en la comunidad de Qumrán, por ejemplo, ver 1Qpls ${ }^{\mathrm{a}}$ fr. 2-6 col. II; Is 10,$22 ;$ Mt 19, 28; 4, 18.
} 
eschaton a sujetos excluidos: pobres, ciegos, cojos, niños, etc. Además, muestra que dicho tránsito, está acompañado con un protagonismo de sujetos escatológicos.

\subsection{Metáforas y sufrimiento}

Ya hemos mencionado que la categoría signos de los tiempos emerge en medio de grupos apocalípticos que sufren la persecución y el martirio. En los siguientes apartados pretendemos mostrar que esta categoría no guarda relación con una 'filosofía de la historia', ni con una interpretación natural de la historia universal, sino con una experiencia 'afectivo-emocional' del tiempo' (Berger, 2011: 145) y que esta experiencia es concomitante con la categoría de 'lugar teológico', la cual es verbalizada mediante una ideología específicamente apocalíptica. En un estudio metaforológico de imágenes neotestamentarias tendríamos que señalar, la periodización de la historia, las metáforas del martirio y las relativas a la señal de Jonás ${ }^{2}$.

\subsubsection{Periodización de la historia}

El concepto de signo de los tiempos responde al supuesto mítico de que la historia está dividida en periodos. Estos periodos o imperios son metaforizados de diverso modo, a veces por metales (Dn 2) o por una serie de 'bestias' (Dn 7); en otros casos se recurre a una diversa calendarización de periodos, 70 semanas de años, 10 Jubileos, el tiempo de Israel, el tiempo de Cristo, el tiempo de la Iglesia o del Espíritu, etc. Este modelo mítico inspiró no sólo los escritos bíblicos sino que el paradigma lo encontramos en Agustín de Hipona, y alcanza incluso a la época medieval con Joaquín de Fiori (Bultmann, 1974). Sin embargo, como ya está dicho, las imágenes míticas del eschaton en Israel son diversas y se expresan utilizando esquemas ideológicos que circulan en su contexto cultural. Este esquema es expresada mediante diversas exprsiones técnicas, por ejemplo 'tiempo del fin' entendido como o

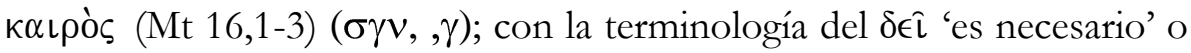
$\pi \rho \omega \hat{\omega} \tau \nu$ 'primero'; en todo estas fórmulas técnicas, la visión mítica del transcurso histórico el paradigma actúa ideológicamente, pues entrega al creyente una estructura ideológica que mediatiza su convicción religiosa. En el mundo semita, la estructura ideológica expresada por medio del mito acompaña normalmente la experiencia creyente. En tiempos

2 El concilio identifica como signos de los tiempos, el martirio como signo supremo del amor y de la coherencia con el ideal de vida (Lumen Gentium 42). 
bíblicos, la actual problemática de una fe pura sin ideología resulta sencillamente impensable, pues el hombre bíblico vive incrustado en el mito, el cual utilizada diversos esquemas ideológicos que pugnan unos con otros.

Incluso en una misma corriente como la apocalíptica, el imaginario de los periodos de la historia, pasa de la imagen cíclica o trascendente, en la primera apocalíptica, a otra dividida en períodos en los apocalipsis llamados históricos. En ambas en sentido es el mismo: «el mito arranca al hombre de su tiempo individual, cronológico, histórico, lo proyecta simbólicamente en el gran Tiempo» (Eliade, 1955: 64) Como ejemplo de esto lo encontramos en Mc 13, 1- 33 par Mt y Lc 21, el discurso escatológico dirigido a una comunidad que es martirizada en la última hora. El flujo del tiempo es guiado por Dios, el cual manda señales que introducen etapas o periodos, esto se indica mediante la partícula $\delta \in \hat{\imath}$ que están situados en los vv. 7.10. 14, y está en relación al uso del adverbio $\pi \rho \hat{\omega} \tau o \nu$ «primero». Esta secuencia o taxonomía de los eventos escatológicos, pretende introducir la importancia de la decisión del creyente en el desarrollo de la historia humana, pero quisiera subrayar el dato incontrovertible para el estudio de la teología neotestamentaria, que desde sus orígenes la categoría de signos de los tiempos ha sido mediada ideológicamente con diferentes usos, tanto para enseñar al creyente, para exhortar, etc.

Esto refleja a nuestro juicio, que los signos de los tiempos, no debe entenderse atomizadamente, como un lexema puntual sino esta expresión remite a una red de otros lexemas metafóricos, que han sido articulados por medio de una ideología y por tanto que debe entenderse como una gramática textual, en la cual se requiere descifrar el sentido de los hechos históricos. Dios envía 'señales' —el martirio y la persecución-, ante las cuales se requiere estar atentos y reconocer el curso de los eventos. El uso de este orden sintagmático refleja una mentalidad mítica que descubre un orden de señales y un sentido entregado por Dios a sus mártires y que muestra que la comunidad marcana comprendió el tiempo final como texto.

\subsubsection{Contexto y tiempo del martirio}

Concomitante con esta experiencia 'esquematizada de la historia', que ciertamente utilizando la terminología de Noemi, produjo históricamente un 'estrechamiento de la teología resultante', muestra que el punto de quiebre de la historia está cerca, los textos apocalípticos judíos y cristianos muestran una constante que es necesario hacer notar. 
El recurso a las señales de los tiempos se da en un contexto de persecución y martirio como incremento del mal en la última hora, así por ejemplo, en los relatos de martirio judío como lo encontramos en Dn 12,1; AscMoisés 8.9-10 y 1QHa; 4Q491 ${ }^{\mathrm{c}}$ encontramos esta tradición, entendida como señal, vinculada a la espera de la irrupción del eschaton. En textos neotestamentarios, no es casualidad que presenten la pasión de Jesús como la del mártir que se prepara para el momento decisivo (ver Mc 14,26s par Lc 22,39s); y si atendemos a la fuente de los dichos, podemos comprobar que se trata de una comunidad radicalizada, posiblemente itinerante y que sufre la persecución (ver Lc 6, 12.20; 7,34; 10,13-15;14,27), así por ejemplo, se menciona que los discípulos deben cargar con la cruz; se argumentar no sólo en el rechazo del Hijo del hombre sino de un plan divino en el cual los enviados de Dios son rechazados, en Lc 11, 49: «...Les enviaré profetas y apóstoles; y de ellos, a unos matarán y a otros perseguirán; para que de esta generación sea demandada la sangre de todos los profetas que ha sido derramada desde la fundación del mundo», considerando esto podemos afirmar que la fuente de dichos responde a un contexto constituida por pobres, excluidos, que tienen conciencia de vivir el eschaton y creen que los enviados de Dios son «asesinados y perseguidos» y que la sangre de los profetas derramada será demandada... esta secuencia se asemeja a la tradición del martirio de los profetas y apóstoles presente en Qumrán como 4Q491' ${ }^{\mathrm{c}}$, en la cual se presupone el envío de profetas en los últimos tiempos y el destino de sufrimiento antes de su exaltación a los cielos (Carbullanca, 2011: 119-131). En todos estos relatos según K. Berger presupone una experiencia del tiempo 'emotiva' desde las víctimas; de modo similar, Malina señala que la experiencia temporal de culturas mediterráneas del siglo primero no es la del tiempo lineal, cronológico sino que ellos experimentan el tiempo como «tiempo experimental», «tiempo imaginario» (Malina, 2004: 220-262). El contexto de persecución y martirio, la identificación de hechos y personajes como la venida de Elías y la del Hijo del hombre, muestran que la expresión señal de los tiempos es utilizada por comunidades apocalípticas y cristianas en contextos bien determinados, a saber, la persecución, la pobreza el martirio. Por tanto, en la discusión sobre la temporalidad de los signos de los tiempos y el discernimiento de éstos en la historia, el lugar desde donde se pretende realizar dicho discernimiento parece radicalmente necesario. $\mathrm{La}$ temporalidad presente en la expresión de los signos de los tiempos se refiere a una historia escrutada desde las víctimas del sistema esclavista, de la persecución y martirio. Este criterio teológico, afecta al lugar teológico desde donde se debe preguntar por los signos de los tiempos en Latinoamérica. 


\subsubsection{Subversión y la señal de Jonás}

El dicho de la señal de Jonás aparece en Mt en dos ocasiones 12, 41 40 y 16, 4, el dicho de Mt 12, 41 par (Lc 11, 29-30), en ambos casos se realiza en un contexto conflictivo en que fariseos y saduceos buscan colocar a Jesús en una situación de 'peligro' pidiendo de él una 'señal de

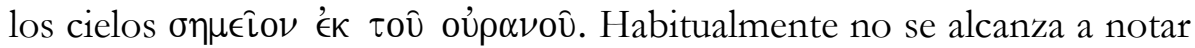
cuál es el peligro y cuál es el sustrato sociosicológico de este lexema. En la literatura del siglo I, el tema de las señales y prodigios tiene relación con un tipo de legitimación de la pretensión política del profeta. Así lo muestra en primer lugar, la legislación mosaica (ver Dt 13, 1-11; 18,2022; 21, 23); ésta preveía, como criterio de discernimiento, para distinguir al seudoprofeta del verdadero, la realización de señales que legitimaran el origen divino de su misión. Según la Ley mosaica el falso profeta debía morir a pedradas por llevar o corromper al pueblo tras otros dioses. Para la legislación judía se trata de delitos políticos contra la nación (Carbullanca, 2010: 353-373). Es así que durante este periodo surgen múltiples seudoprofetas que prometen repetir los signos escatológicos del primer éxodo ${ }^{3}$. Es importante anotar el recurso al mito de los orígenes, pues dichos 'profetas' se consideran a sí mismos como un 'nuevo Moisés' y por consiguiente su misión no se reduce al ámbito religioso sino también político. Este aspecto político de las señales es ilustrado claramente por Flavio Josefo quien expresa cuál es el problema de estos falsos profetas en Jewish War (1979: cap. 2, 259) «Estos fueron hombres impostores y engañaban al pueblo con el pretexto de tener una

3 En algunos textos neotestamentarios el falso profeta es llamado «mago» (ver Hch 13,6); Flavio Josefo les llama un yón's que se traducecomo «charlatán», «impostor».

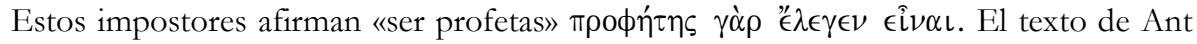
20,50.1 describe a Teudas como un «mago», «un impostor», «un adivino», «un mago», pero es importante notar que este «mago» tiene la pretensión política de realizar una revolución armada y cambiar el orden político. Se trata entonces, de «profetas» o que se consideran a sí mismo como tales, según la opinión de Flavio Josefo se trata de «locos», «endemoniados», «posesos» y «seudoprofetas» En otro texto Josefo, Ant 20, 8, 6 «los impostores y los hombres falaces persuadían a la multitud que los siguieran al desierto. Decían que allí les mostrarían signos y señales que sólo pueden producirse por obra y providencia de Dios. Muchos que les creyeron sufrieron los castigos que merecían su locura, pues Felix los hizo ejecutar cuando le fueron entregados». Esto se puede comprobar por las imágenes que se utilizan: sus seguidores son guiados hasta el río Jordán, donde se abrirían las aguas del río y se realizaría un nuevo signo del éxodo. En estas noticias encontramos que el tema de seguir a estos «impostores» al desierto se repite (ver Ant 20, 8, 6); estos seudoprofetas e impostores persuaden ('€ $\pi \epsilon \iota$ ov $)$ al pueblo de ir al desierto. Un lugar predilecto para realizar las señales mesiánicas; pero en otro caso que menciona Flavio Josefo en Ant 20,8.6 'el egipcio' pretende ser un profeta que mostraría la caída de las murallas de Jerusalén. 
inspiración divina, pero querían realizar sediciones y cambios de gobierno, y éstos convencían al pueblo de su locura y conducían a ellos al desierto, pretendiendo que Dios debía mostrar allí los signos de la libertad». Añadamos a esto, que la causa por la que es asesinado Juan Bautista según el informe de Flavio Josefo, habría sido el peligro de la subversión política, así lo expresa en Jewish Antiquities (1998: cap. 18, 117 119): «la gran influencia de Juan sobre el pueblo temía que esto condujera a una rebelión». Por tanto, es importante atender que la metáfora de las 'señales del cielo' tuvo para los contemporáneos de la comunidad mateana una connotación política, entendida como una llamada a la subversión y legitimación política ante el pueblo. Este es un primer elemento importante a desentrañar en la expresión estudiada. Ella pertenece al ámbito del conflicto político-religioso. Pero además, es importante la función legitimadora que posee la expresión. Es notable que en relación a las señales prometidas por estos impostores se repita en

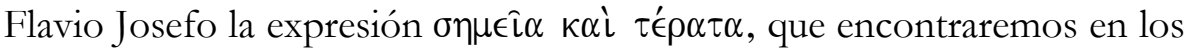
textos neotestamentarios para referirse a los seudoprofetas y anticristos que aparecen en los últimos tiempos antes de la vuelta del Hijo del hombre (ver Lc 21 ,22; Mc 13, 22; 2Tes 2,1; Did 16,4). Es interesante que en estos textos se mencione las señales como elemento fundamental legitimador de la función del «imposton», tanto profetas o 'magos' llevan al pueblo al desierto y muestran las señales de la liberación o signos de la solución de todos sus males.

Como está expresado, en los textos de Flavio Josefo, la convicción de un profeta escatológico como Moisés, que realizaría las señales de último éxodo es concomitante con la expresión 'señales de los cielos'. Si bien, esta expectativa es un lugar común entre grupos apocalípticos. En los textos de Flavio Josefo faltan los elementos de sufrimiento y martirio que acompañan a este personaje carismático y que encontramos en algunos grupos judíos de esta época. Si bien es cierto que el profeta debía realizar las señales de Éxodo de acuerdo a los textos de Is 61,1-2; 35,5, 4Q521; 11QMelq, etc. En algunos textos de Qumrán encontramos que este profeta debía sufrir y padecer el martirio - como todos los profetas- y luego ser exaltado (1QHa). Por tanto, como lo muestran diversos textos, la experiencia del martirio como señal de los tiempos se comenzó a incubar en tiempos pre-cristianos (ver 4QpNa; 1QHa; Dn 9,23; Za 13,7) y fue utilizada posteriormente por las comunidades cristianas para comprender los últimos tiempos. La novedad radicará en la interpretación histórica que se muestra en el relato: el anuncio del evangelio a los paganos. 
En el relato de Mt 16,1-3, se añade al dicho de Jonás, los vv. 2-3 que compara las nubes y la señal de los tiempos (ver Lc 12, 56). Lucas

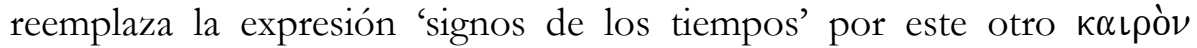

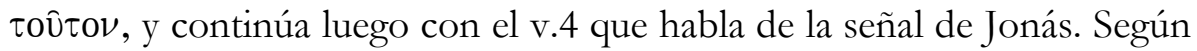
esto es claro, que para Mateo la señal de los tiempos responde a un acontecimiento central que se identifica con la muerte de Jesús pero que se manifiesta en el anuncio del evangelio a los paganos. La tensión metafórica que presenta la imagen de Jonás es potente, el mar, los ninivitas, los tres días y tres noches remiten a un contexto de crisis eclesial perteneciente al periodo post-pascual. La 'única señal' la señal de Jonás, será entendida como una metáfora, el tránsito de un profeta que se niega a tener misericordia de un pueblo impío, al anuncio del kerigma a los ninivitas [paganos]. Tanto el kerigma del profeta así como los tres días que el profeta en el vientre de la Ballena tensionan el sentido en función del tránsito de la Iglesia mateana: el martirio y rechazo del Hijo del hombre, abre a la Iglesia a la gentilidad, por tanto, este descenso de Jonás/Hijo del hombre, se constituye en una señal de una crisis eclesial; y por tanto, esta situación es una 'señal del tiempo paradójica' pues a causa de su muerte se anuncia el evangelio a los paganos. La señal de Jonás la vinculación histórica de toda metáfora. Representa una metáfora que describe el proceso histórico del tránsito de la Iglesia constituida por judíos a otra en medio de las naciones.

Sumario. La iglesia ha reconocido reiteradas veces, el martirio como una señal de los tiempos. A partir del estudio de las metáforas referidas a este motivo encontramos que el mitema está vinculado a una representación ideológica de la temporalidad de carácter apocalíptico. Esta ideología es utilizada por diversos relatos neotestamentarios para indicar que las señales están entendidas dentro de una gramática del eschaton y que revelan la hora decisiva del drama cósmico. Además, estas imágenes muestran que se trata de un 'tiempo experiencial', 'subjetivo' interpretado desde un contexto especifico de crisis y conflicto político-religioso que lleva a las comunidades a escrutar la historia para reconocer en ella las señales del eschaton o de la venida del Hijo del hombre. De manera especial pareciera que la comunidad mateana comprendió la señal de Jonás como una situación crítica y que presupone una comprensión de la figura de Jesús de Nazaret, como líder carismático, subversivo, en el marco del pacto pragmático que presupone este término en el siglo I. La comunidad mateana ha entendido en cambio la señal de Jonás como la crisis que ha desencadenado la muerte de Cristo, el tiempo kairológico del paso de una Iglesia judeo-cristiana a otra constituida por paganos. 


\section{Metáforas y topografía de revelación}

El tema de la mundanidad y los signos de los tiempos es un tema particularmente relevante para el tema que nos toca. Ya hemos mencionado que la expresión 'signos de los tiempos' presupone un concepto de revelación vinculado a 'espacios y lugares', más que a 'fuentes', a esto nos referiremos con una topografía revelatoria del eschaton: «la única efectivamente real, y no de una geografía profana...», como señala M. Eliade (1955: 43). Esta topografía imaginaria, está vinculada a metáforas que muestra un espacio mítico - el trono celeste, el templo de Jerusalén, el monte Sión o Galilea- que relatan el espacio real por antonomasia. Este espacio, así como el carácter enigmático, al cual también nos referiremos, introducen el lenguaje de la revelación en el ámbito de la estética, en cuanto la otra orilla y el enigma expresan 'la alteridad' en un espacio marginal como categoría inherente a la revelación.

En las siguientes apartados estudiaremos la tensión metafórica 'templo-pasar a la otra orilla', como lugar estético de revelación. Posteriormente, nos centraremos en un dato fundamental de muchos textos neotestamentarios que remiten al modo de revelarse del Dios de Jesucristo, en cuanto pregunta que interroga y que coloca en juego el ser del hombre en su radical horizonte de realización.

\subsection{Revelación y lugar teológico: la metáfora del 'pasar a la otra orilla'}

Para el judaísmo del siglo I, el lugar de Dios está en los cielos, la revelación había acontecido en los orígenes en monte Sinaí, y posteriormente, el nombre de Yahvéh habitaba en el templo como 'metáfora', 'señal' de la presencia divina en medio de su pueblo. En este sentido, la expresión signo de los tiempos está contrapuesto al del templo, jerarquía sacerdotal y todo su aparato, en cuanto símbolo de su presencia ${ }^{4}$. Al respecto los textos de Jn 2,18; Mc 11,15-18 son expresivos. Una de las notas características de estos es la violenta crítica que sufre el antiguo templo, siendo deslegitimado como lugar donde acaece la revelación divina. La metáfora de la presencia divina en el templo responde a la mitología de un mundo estratificado en el cual el templo es

\footnotetext{
4 Dionisos expone en la De coelesti hierarchia en De Ecclesiatica hierarchia, a la jerarquía eclesiástica como imagen de la celeste. El mundo de los hombres participa de los bienes celestes a través de la mediación de la jerarquía eclesiástica, que a su vez la recibe por mediación de la jerarquía celeste.
} 
el «centro», 'el lugar más alto', de este cosmos. El templo es el reverso mítico de la topografía sagrada de la periferia o de la otra orilla. Aquella topografía metafórica es estática, en cambio, la periferia o la orilla responde a una metafórica dinámica, o más bien, 'la orilla', descubre a un Dios que camina, que corre o que lleva o hace del profeta una 'metáfora' de la propia vida. Recordemos que a esta isotopía pertenece la carroza divina, es un Dios con ruedas (Ez 1,26) que se mueve hacia los cautivos de Babilonia, los excluidos u oprimidos. De la misma manera en los evangelios están estructurados metafóricamente desde el 'transito' entendido como 'paso', del evangelio del mundo judío al mundo grecoromano. Entonces no es extraño encontrar a Jesús frecuentemente 'metaforizando', cruzando o yendo «a otra parte, a los pueblos vecinos» $(1,38)$; en numerosas ocasiones cruza el mar de Galilea (ver 1, 9.14), en otras, camina o enseña junto al lago (ver 1,$16 ; 2,13 ; 3,7 ; 4,1)$. De manera especial gusta de «pasar a la otra orilla» (ver 3,$8 ; 4,35 ; 5,1 ; 10,1)$. Esto no es casual, la figura de Jesús es una metáfora que lo cambia todo. En él, Dios sale al encuentro, y cruza los límites impuestos por la Ley judía. Este transito muestra una gramática de la revelación de la comunidad marcana. 'Cruzar el mar', y ciertamente la 'pequeña barca' representa una potente imagen onírica del nuevo lugar teológico que se traslada de una a otra orilla para liberar a los cautivos.

De la misma manera que lo hemos mencionado en las metáforas de la infancia, esta gramática topográfica del Dios que se pasa a 'la otra orilla' refleja una inversión de la ideología de una estratificación jerárquica de seres; que se expresa como una inversión cósmica y social de los protagonistas del eschaton, ya no son los judíos quienes escuchan el evangelio sino los campesinos y esclavos del mundo pagano. Si el mito del «centro» legitima a los sacerdotes, y autoridades judías, la metáfora del 'pasar a la otra orilla', implica una inversión de sujetos. Esto es importante atendiendo a una teología de los signos de los tiempos, pues a diferencia de la topografía sagrada del «centro» que fundaba una jerarquía socio-religiosa judía -que prohibía el comercio con los paganos, y por tanto segregadora -, el Dios que se da a conocer en la periferia establece como revelación una realidad integradora de sujetos excluidos, parias de ese mismo espacio. El topos sagrado del «centro» establece la Ley de la exclusión, en cambio esta imagen metafórica, que es la estructura economía del evangelio, postula como lugar teofánico el espacio fuera o al otro lado de los márgenes sagradas. Esto mismo es lo que afirma el relato de Mc 4, 35: «...llegó la noche, les dijo: - Pasemos al otro lado». La imagen de la noche y del mar evoca un isomorfismo con la imagen de la muerte acuática del signo de Jonás. No es casual este isomorfismo. El evangelio señala que Jesús muere por 'los muchos' esto 
es, el mundo pagano (Mc 14,24). De acuerdo a los evangelios sinópticos, la muerte de Jesús acontece a causa de los paganos, los ninivitas del signo de Jonás. El agua es símbolo de muerte y vida, la vida emerge de las aguas primordiales, del bautismo y del diluvio relacionan el mundo nuevo con la imagen de la infancia que ya hemos mencionado. El nacimiento del mundo nuevo y el infante proceden del mar que traga: 'la infancia es un agua humana' dice Bachelard (1982: 170). El lugar de la comunidad eclesial post-pascual es éste, el permanente pasar a la otra orilla, como el Dios que se mueve. En otras palabras, la comunidad eclesial, se constituye en la crisis del morir acuático representado por el dejar la tierra conocida, y un nacer de nuevo en otra tierra para anunciar el reino.

\subsection{La revelación como enigma e interrogación}

El estudio de la metáfora de la 'señal de Jonás' nos ha llevado a entender que la cuestión de los signos de los tiempos presenta un concepto de revelación expresado como 'enigma'. La teología católica acostumbra a discutir dicho concepto en relación a doctrinas, o más cercanamente, referido al Concilio Vaticano II, por medio de 'gestos y palabras' queriendo con esto, subrayar el carácter histórico de la revelación. Sin embargo hay que aportar a este concepto de revelación un aspecto estético que muestran los textos neotestamentarios relativos a las señales de los tiempos. Dicha revelación tiene el carácter de desazón y enigma que atrae (Oyarzún, 1981: 42). Las palabras y gestos de Jesús producen una extrañeza inscrita dentro de la gramática del enigma y del juego sagrado, que lo emparenta a la experiencia estética en que se encuentra el arte moderno. Las palabras que Oyarzún nos ayudan (1981: 42). Éste dice en relación al arte moderno: «se trata de una extrañeza con identificación, de una extrañeza con un esbozo de identificación por lo menos, como que sentimos a este arte de algún modo significativo». El carácter paradojal de este hecho lo subraya Oyarzún (1981: 42) «es curioso sentirse identificados con algo que nos es extraño». Si hay algo que atrae al hombre de hoy es la profunda desazón que produce el enigma que rodea la persona de Jesús. Estas consideraciones, nos ayudan a comprender el carácter estético del enigma que rodea a la persona de Jesús y que caracteriza la cultura postmoderna.

La Sagrada Escritura muestra un hecho notable, Dios manifiesta su plan en forma de pregunta, el proyecto de Dios no es algo ostensible sino que su propio revelarse histórico al hombre tiene carácter interrogativo. Al profeta Isaías, $(6,8)$ pregunta: «escuché la voz del Señor, que decía: -¿A quién enviaré? ¿Y quién irá por nosotros?». La doble 
pregunta de Dios refleja la urgencia y el imperativo del envío del profeta. Dios pregunta, interpela, en función de una misión una praxis, así por ejemplo, en el relato del llamado de Elías de 1Re 13, 13: «Cuando Elías lo oyó (la palabra divina)... llegó una voz que le decía: - ¿Qué haces aquí, Elías?». Sus preguntas no tienen un carácter retórico, literario, sino que más bien mediante la pregunta, Dios pretende abrir, suscitar en el creyente a la búsqueda de un sentido, una esperanza en la desilusión o en la amargura (Lc 24,17-19). La Palabra de Dios es interrogación por esto, a los profetas y a Jesús los rodea el silencio y el enigma. Es importante atender a la diferencia de enfoque que posee este elemento enigmático. La exegesis del siglo pasado, ha considerado dichos relatos como 'Streitgesprach', o 'discusiones de escuela', no obstante el estudio de las religiones ayuda a mostrar que estas discusiones responden a una cuestión anterior. Huizinga (1957: 143-159) define este juego de preguntas y contra-preguntas como un juego sagrado, con reglas y que suele ocurrir en un ambiente lúdico. No es casual que la compañía de Jesús, sea enigmática y que los diálogos entre que él y sus discípulos ocurren en esta atmósfera sagrada. Las preguntas por la identidad del traidor, por la hora de la restauración, por el fin del mundo, es necesario inscribirlas en este horizonte. Tomando en consideración esto, la misma imagen revelatorio de las 'anécdotas' neotestamentarias es radicalmente distinta. Entonces, no se trata tan sólo de acreditar una cuestión relativamente histórica, sino más allá de esto, la manera como se trata esta muestra algo profundamente significativo para el creyente. A la revelación cristiana le acompaña una cierta extrañeza inherente al misterio que la constituye; ésta siendo histórica, no es algo ostensible, a la mano. No se identifica sin más con una arquitectura de verdades, sino que tiene carácter interrogativo. Las formas narrativas (parábolas, símil, símbolos, etc), así como las preguntas no apunta a dar una información doctrinal, sino que éstas exponen al jugador a un juego que relaciona conocimiento y vida. Pareciera que el recurso al enigma, refleja un principio hermenéutico del conjunto de la revelación cristiana. El enigma así como la pregunta divina, lleva en la misma pregunta una respuesta a la situación del hombre, y por tanto posee en sí misma una estructura anticipatoria.

La exegesis del siglo pasado ha querido mostrar el texto bíblico como razonable e 'histórico' y tiene razón, pero el estudio de los textos religiosos muestra que las preguntas no sólo pretenden entregar una información, sino que llevan al discípulo a una realidad mayor. Los textos bíblicos en general, son profundamente incoherentes, anónimos, fragmentarios y enigmáticos. El relato de Mc 9, 11: «¿Por qué dicen los escribas que es necesario que Elías venga primero?», expresa claramente 
la gramática supuesta por los discípulos. Se trata de una convicción asumida por los escribas y discípulos acerca de la vuelta de Elías (ver Mal $3,23)$. No obstante, el texto sitúa teológicamente la convicción de esta comunidad, a partir del v. $12 \mathrm{~b}$ a través de un cambio de horizonte por medio de otro enigma. En el v. 12b se coloca en evidencia el paralelo entre Elías y el Hijo del hombre al vincular otro motivo imaginario ya no del estado final, sino del martirio de Elías y del Hijo del hombre: "¿no dice la Escritura que el Hijo del hombre debe padecer mucho y ser despreciado?». Esta doble interrogante coloca en evidencia una cuestión insólita. No hay texto bíblico que hable del sufrimiento del Hijo del hombre. La pregunta por los sufrimientos del Hijo del hombre, está inscrita en esta gramática del mundo mítico. Esta incoherencia expresa algo más que un contratiempo exegético y un entretenimiento retórico, refleja más bien el modo cómo la comunidad pensó el proceder de Dios en la historia. La aporía textual remite a un modo de proceder del Dios liberador y salvador. La pregunta presupone que la comunidad acepta la venida de Elías como señal del los tiempos y que éste ha sido martirizado en la persona de Juan el Bautista. La incoherencia textual, que refleja esta tradición, comprendió la pasión del Hijo del hombre a partir de una gramática o pacto lingüístico a la que pertenecía la tradición martirial de Elías: así como Elías (o los profetas) ha sufrido y muerto a manos del pueblo infiel, así el Hijo del hombre deberá padecer y morir. Entonces, la incoherencia escriturística se transforma en una cuestión acerca del modo de mostrarse el Dios que actúa en la historia salvífica. Algo similar encontramos en el grito de Jesús en la cruz: «¿Dios mío, Dios mío, porqué me has abandonado?». No se trata de una pregunta abstracta, ni de una aporía metafísica, sino de las preguntas históricas que hace el creyente oprimido ante la injusticia que padece. Entonces, las palabras del pobre y del justo muestran en su carácter interrogativo, muestran una praxis que emerge de la pregunta. No puede ser de otro modo, la historia interroga al hombre y éste a Dios, porque ambos son una pregunta por responder. El ser de Dios en la cruz se vuelve un enigma que interpela y lleva a hombre a ponerse en camino.

Sumario. Las expresiones relativas a los signos de los tiempos están formuladas de acuerdo a una determinada topografía que presupone la creencia que el Dios del reino se manifiesta en la 'otra orilla'. Esto muestra además una crítica al templo como lugar teológico donde se manifiesta el Dios del reino. El hecho de que los evangelios estén diseñado bajo la metaforización del 'pasar a la otra orilla' o en términos teológicos a partir de la pascua, expresa la radical importancia de esta topografía en vista de pensar la categoría de revelación en términos de 
'lugar teológico' y no de 'fuentes'. Además, como lo hemos mostrado, a la categoría de señal de los tiempos le es inherente un carácter enigmático, lo cual se expresa a través de los géneros utilizados en los evangelios. De manera particular, hemos expresado que las preguntas que acompañan a los relatos evangélicos muestran que la revelación divina en Cristo acontece en forma de pregunta histórica.

\section{Palabras finales}

Hemos sostenido que en vista de superar lo que parece 'déficit' (Ruggieri), o una 'aporía insuperable' (Noemi), de una teología de las señales de los tiempos, se requiere levantar una nueva epistemología, estética, consistente en una retirada de la razón metafísica a favor de una epistemología basada en la fuerza cognitiva de la metáfora que vio nacer los conceptos teológicos sobre los cuales se ha levantado y formulado la historia de la teología de Occidente. Hemos insistido que la precaria situación de la teología especulativa, que menciona Sander, postula una 'Sprachlosigkeit' 'silencio creativo' que ayude a colocar de relieve la diferencia que media entre la manera de comprender nuestra temporalidad y la de los tiempos neotestamentarios. El término 'señal de los tiempos' emerge desde grupos apocalípticos marginales anteriores y contemporáneos al siglo I, que creen vivir los últimos tiempos. Es posible que el uso de la expresión en el documento conciliar, y en el papa Juan XXIII, no se reduzca a una casualidad, sino que deliberadamente proponga interpretar la historia e identidad eclesial dentro de este paradigma mítico, el cual nosotros hemos desarrollado en este artículo.

Si esto es así es importante una metaforología o una teología metafórica que nos ayude a comprender la irrupción del eschaton en nuestro tiempo. Nosotros hemos investigado las metáforas que relacionan los signos de los tiempos con las metáforas de la infancia; hemos insistido que estas guardan relación con un paradigma político, esto es, la irrupción de un nuevo imperio o era mundial. Esta nueva era, contiene caracteres políticos e históricos, de manera particular establece que a ésta le acompaña una ruptura epistemológica con el anterior periodo, según lo cual, las señales son reconocidas por 'los niños' y se les ha ocultado a los pecadores. Dicha metáfora es utilizada en la praxis de Jesús, en relación no a sí mismo, sino a sujetos marginados. Este cambio refleja una praxis anti-mesiánica que anticipa el tiempo escatológico y el principio epistemológico de la cruz que caracteriza el evangelio. Al respecto, Rugieri (2006: 68) tiene razón cuando afirma que «la comprensión de la señal de los tiempos pertenece propiamente no a la teología sino a la 
experiencia teológica de la comunidad». Se trata por tanto de una inversión epistemológica mediante la cual, la acción política está comprendida desde la experiencia estética de la praxis del Reino realizada por los excluidos. En este sentido, una criteriología de los signos de los tiempos, pedida por M. Vogt debe integrar la 'parcialidad' y el carácter conflictivo que es inherente a la categoría de los signos. Además, en nuestro estudio hemos sostenido que son esenciales a dicha metáfora, tanto las categorías de 'lugar teológico' como la de 'sujetos escatológicos' por tanto, no se reconocen los signos desde cualquier lugar ni todos acceden a dicha comprensión. Pero también, este reconocimiento de los signos en el mundo, legitima y constituye en comunidad profética, a sujetos que secularmente son considerados excluidos: pobres, ciegos, cojos y niños.

Los relatos analizados muestran que la comunidad eclesial constituida por el reconocimiento de los signos de los tiempos es una comunidad profética, y señalan que se trata de una comunidad que experimenta la persecución y el martirio. A partir del estudio de las metáforas referidas al motivo del martirio, encontramos que éstas están vinculadas a mediaciones ideológicas de la temporalidad dividida por periodos de origen apocalíptico. Esta 'esquematización ideológica', así como la 'estratificación de seres' es utilizada por diversos relatos neotestamentarios para indicar que el incremento de la injusticia responde a un plan diseñado de antemano y que el relato expone en vista de exhortar a su comunidad a interpretar la historia presente como la hora decisiva del drama cósmico. Además, hemos insistido que dichas imágenes muestran que en toda esta terminología temporal se trata de un 'tiempo experiencial', 'fragmentario' y 'subjetivo' interpretado desde un contexto teológico de sufrimiento específico que lleva a las comunidades a poder discernir y escrutar la historia y rogar a Dios que acelere la hora del juicio. De manera especial, pareciera que en textos neotestamentarios, la comunidad de la fuente de los dichos y luego la comunidad mateana comprendió la señal de Jonás como una crítica a la ideología de las señales y entendió el mesianismo de Jesús de Nazaret en el marco del pacto pragmático que presupone este término en el siglo I; mostrando que el signo de Jonás, la muerte de Cristo, expresa un tiempo kairológico, el paso de una Iglesia judeo-cristiana a otra constituida por paganos.

Esto mismo lo hemos colocado en evidencia en las expresiones metafóricas relativas al espacio sagrado. Si para la teología judía no era evidente una revelación actual de Yahvéh que se realizara al margen del Templo, todavía más radical parece sostener una revelación en medio, no sólo del mundo, sino del mundo de los excluidos. La topografía 
metafórica que hemos estudiado, expresa un giro en el concepto de revelación, pues presupone que el Dios verdadero se manifiesta en la 'otra orilla' y revela una crítica al Templo y a su aparato como mediación y lugar teológico donde se manifiesta este Dios. El hecho de que los evangelios estén diseñado bajo esta metáfora de la 'Pascua', expresa una cuestión de radical importancia en vista de pensar la categoría de revelación en términos de 'lugar teológico': el Dios que camina es un Dios vivo que no se deja cosificar en sistema religioso alguno. Esto mismo, como lo hemos desarrollado al mostrar que al término 'señal de los tiempos' le es inherente un carácter enigmático, lo cual se expresa no sólo a través de los géneros utilizados sino que la praxis e identidad del mesías acontece en forma de pregunta histórica.

\section{REFERENCIAS}

-Agis, M. (1997). Metáfora y filosofía. En torno al debate Paul Ricoeur-Jacques Derrida, Metáfora y filosofía, Cuaderno gris, (2), 301-316.

-Bachelard, G. (1982). La poética de la ensoñación, México: Fondo de Cultura Económica.

-Berger, K. (2011). Psicología histórica do Novo Testamento. Sao Paulo: Paulus.

-Berrios, F., Costadoat, J. y García, D. (2008). Signos de estos tiempos. Interpretación teológica de nuestra época. Santiago de Chile: Universidad Alberto Hurtado.

-Bultmann, R. (1974). Historia y escatología. Madrid: Studium.

-Carbullanca, C. (2008). Los signos de los tiempos en el evangelio de Marcos. Aproximaciones al sentido teológico de la historia y la Escritura en el segundo evangelio. Teología y Vida XLIX (4), 649-672.

-Carbullanca, C. (2010). Jesús seudoprofeta y corruptor del pueblo. Una lectura pragmática de Dt 21,20-23 en el dicho de Q 7,34. Anales de Teología de la Universidad Católica de la Santísima Concepción, 12 (2), 353-373.

-Carbullanca, C. (2011). ¿Una teología del martirio en 1QHa y 4Q491c? Aportes para la comprensión de la cristología del Hijo del hombre joánico. Veritas, (25), 119-131.

-Chauvet, L. (1991). Símbolo y sacramento. Barcelona: Herder.

-Costadoat, J. (2008). Los signos de los tiempos en la Teología de la liberación. En F. Berrios, J. Costadoat, D. García, Signos de estos tiempos. Interpretación teológica de nuestra época (págs. 131-148). Ed. Universidad Alberto Hurtado, Santiago de Chile.

-Derrida, J. (1978). La retirada de la metáfora. En Po \& sie (7), 103-126. Disponible en: http://www.jacquesderrida.com.ar/textos/metafora.htm. Texto consultado: 13 de marzo de 2012.

-Derrida, J. (2007). White Mythology. Metaphor in the Text of Philosophy. Oxford: John Hopkins University Press.

-Durand, G. (1968). La imaginación simbólica. Buenos Aires: Amorrortu. 
-Durand, G. (2004). Las estructuras antropológicas de lo imaginario. México: Siglo XXI.

-Eliade, M. (1955). Imágenes y símbolos. Madrid: Taurus.

-Gera, L. (2005). Teología de los procesos históricos. Revista Teológica XLII (87), 259-279.

-González, A. (2003). Reinado de Dios e Imperio, Santander: Sal Terrae,

-Gonzalez-Carvajal, L. (1987). Los signos de los tiempos. El reino de Dios está entre nosotros. Madrid: Sal Terrae.

-Hartmann, L. (1966). Prophecy Interpreted. The Formation of some Jewish Apocalyptic texts and of the Eschatological Discourse Mark 13 par. Upsalla: Almquist \& Wiksells Boktryckeri AB.

-Heidegger, M. (1954). Kant y el problema de la metafísica. México: Fondo de Cultura Económica.

-Heródoto (1990). Historias I. (Ed. Jaime Berenguer). Madrid: Consejo de Investigaciones Científicas.

-Huizinga, J. (1955). Homo Ludens. Buenos Aires: Emece Editores.

-Hünermann, P. (Hrsf) (2006). Das Zweite Vatikan Konzil und die Zeichen der Zeit beute. Anstosse zur weiteren Rezeption (Festschrift für Kardinal Lehmann). Freiburg: Herder.

-Josephus, F. (1997). Works: The Jewish War (Bks. III-IV v. 3). Guernsey, GY, United Kingdom: Harvard University Press.

-Josephus, F. (1998). Works: Jewish Antiquities, (Bks. I-III v. 5). Guernsey, GY, United Kingdom: Harvard University Press.

-Lakoff, G. y Johnson, M. (2003). Metaphors we live by. London-Chicago: The University of Chicago Press.

-Lapoujade, M. N. (1988). Filosofía de la imaginación. México: Siglo XXI.

-Levi Strauss, Claude. (1962). El Pensamiento salvaje. FCE, México.

-Malina, B. (2004). O evangelho social de Jesus. O reino de Deus em perspectiva mediterranea. Sao Paulo, Paulus.

-Marcuse, H. (1968). Eros y civilización. Barcelona: Sex Barral.

-Nietzsche, F. (1998). Sobre la verdad y mentira en sentido extramoral. Madrid: Tecnos.

-Noemi, J. (1998). Rasgos imperativos y desafíos. En J. Noemi y F. Castillo, Teología latinoamericana (págs. 11-93). Santiago de Chile: Centro Ecuménico Diego de Medellín.

-Noemi, J. (2008). En la búsqueda de una teología de los signos de los tiempos. En F. Berrios, J. Costadoat y García, Signos de estos tiempos. Interpretación teológica de nuestra época (págs. 83-98). Santiago de Chile: Ed. Universidad Alberto Hurtado.

-Oyarzún, L. (1981). Ideas sobre el arte contemporáneo. Meditaciones estéticas. Santiago de Chile: Editorial Universitaria.

-Parra, F. (2008). Desafios del tiempo, memoria y esperanza. En F. Berrios, J. Costadoat y D. García, Signos de estos tiempos. Interpretación teológica de nuestra época (págs. 47-82). Santiago de Chile: Ed. Universidad Alberto Hurtado.

-Ricoeur, P. (1980). La metáfora viva. Madrid: Ediciones Europa. 
-Ricoeur, P. (1984). Poética y simbólica. En Hanret et al. (eds.), Iniciación a la práctica de la teología. I. Introducción (págs. 43-69). Madrid: Cristiandad.

-Ruggieri, G. (2006). Zeichen der Zeit. Herkunft und Bedeutung einer christlich-hermeneutischen Chiffre der Geschichte. En P. Hünermann (Hrsf): Das Zweite Vatikan Konzil und die Zeichen der Zeit beute. Anstosse zur weiteren Rezeption (Festschrift für Kardinal Lehmann) (págs. 61-70). Freiburg: Herder.

-Snder, H. J. (2003). In der Zeichen der Zeit die Lehren des Glaubens zumuten. Salzburger Theologische Zeitschrift, 7, 51-61.

-Sartre, J. P. (1973). La imaginación, Buenos Aires: Ed. Sudamericana.

-Vogt, M. (2006). Den Schrei der Schöpfung horen das ökologische Bewusstsein als "Zeiche der Zeit". En P. Hünermann (Hrsf): Das Zweite Vatikan Konzil und die Zeichen der Zeit heute. Anstosse zur weiteren Rezeption (Festschrift für Kardinal Lehmann), (págs. 122-145). Freiburg: Herder.

-Volz, P. (1903). Jüdische Eschatologie von Daniel bis Akiba. Tübingen/Leipzig: J. C. B. Mohr.

Sumario: 1. La metáfora en la Sagrada Escritura; 1.1. Estética y retorno a la Sagrada Escritura; 1.2. Las metáforas del tiempo bíblico; 1.3. Mito-logos y metáfora; 2. Una lectura estética de los signos de los tiempos; 2.1. Pensar una

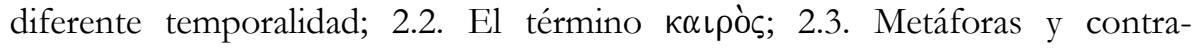
proyecto cultural; 2.4. Metáforas y sufrimiento; 2.4.1. Periodización de la historia; 2.4.2. Contexto y tiempo del martirio; 2.4.3. Subversión y señal de Jonás; 3. Metáforas y lugares de revelación; 3.1. Revelación y lugar teológico: la metáfora del 'pasar a la otra orilla'; 3.2. La revelación como enigma e interrogación; 4. Palabras finales; Referencias. 